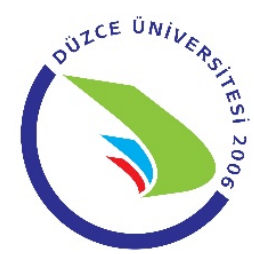

\title{
Jinekolojik Onkoloji Palyatif Bakımda Simülasyona Dayalı Mesleklerarası Eğitime Yönelik Öğrencilerin Görüşleri: Nitel Çalışma
}

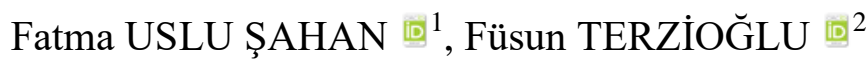

ÖZ

Amaç: Bu araştırmada, jinekolojik onkoloji palyatif bakımda simülasyona dayalı mesleklerarası eğitime yönelik öğrencilerin görüş, düşünce ve önerilerinin belirlenmesi amaçlanmıştır.

Gereç ve Yöntemler: Araştırmada nitel araştırma yöntemlerinden yorumlayıcı fenomenolojik yaklaşım kullanılmıştır. Araştırmanın uygulaması Nisan 2017 - Mayıs 2017 tarihleri arasında gerçekleştirilmiştir. Araştırmanın örneklemini 28 öğrenci (sekiz hemşirelik, sekiz beslenme ve diyetetik, sekiz sosyal hizmet ve dört tıp öğrencisi) oluşturmuştur. Araştırmanın verileri sosyo-demografik bilgi formu ve yarı yapılandırılmış odak grup görüşmesi soru yönergesi ile dört odak grup görüşmesi yapılarak toplanmıştır. Görüşmelerden elde edilen veriler tümevarım yaklaşımı ve içerik analizi yöntemi kullanılarak değerlendirilmiştir.

Bulgular: Öğrenciler ile yapılan görüşmeler sonucunda ortaya çıkan temalar (1) "palyatif bakım hizmeti sunumunda ekip yaklaşımı" (2) "Mesleklerarası Jinekolojik Onkoloji Palyatif Bakım Eğitimi”; (3) "Simülasyona Dayalı Mesleklerarası Jinekolojik Onkoloji Palyatif Bakım Eğitimi” olarak sıralanmıştır. Araştırmada öğrenciler, palyatif bakımda ekip çalışması ve mesleklerarası eğitimin önemini daha iyi anladıklarını; diğer mesleklerin rol ve sorumluluklarını öğrenebilmek, ekip olarak çalışabilmek, hasta güvenliğini ve hasta merkezli bakımın sağlayabilmek için simülasyona dayalı mesleklerarası eğitimin gerekli olduğunu belirtmişlerdir. Öğrenciler lisans eğitim müfredatlarında simülasyona dayalı mesleklerarası eğitimin gerekliliğini vurgulamışlardır. Öğrencilerin simülasyon uygulamaları ile teorik eğitimde öğrendiklerini daha iyi pekiştirdikleri, yanlışlarını/hatalarını düzeltme firsatı buldukları, mesleki profesyonelliklerinin farkına vardıkları belirlenmiştir.

Sonuç: Sağlık profesyonellerinin eğitiminde mesleklerarası simülasyon uygulamalarının kullanımı için eğiticilerin ve öğrencilerin teşvik edilmesi ve lisans eğitim müfredatlarına entegre edilmesi önerilmektedir.

Anahtar Kelimeler: Hemşirelik araşıırması; jinekoloji; kanser; niteleyici araştırma; palyatif bakım; sağlık ekibi; simülasyon eğitimi.

\section{Students' Views on Simulation-Based Interprofessional Training in Gynecologic Oncology Palliative Care: A Qualitative Study}

\begin{abstract}
Aim: In this study, it was aimed to determine the opinions, ideas and suggestions of the students about simulation-based interprofessional training in gynecologic oncology palliative care.

Material and Methods: The research is a qualitative study using an interpretative phenomenological approach. The study was conducted between April 2017-May 2017. The sample consisted of 28 students (eight nursing, eight nutrition-dietician, eight social worker and four medical students). The data were collected through four focus group interviews with socio-demographic information form and semi-structured focus group interview question directive. The data obtained from the interviews were evaluated by using the inductive approach and content analysis method.

Results: Themes resulting from interviews with students (1)"the team approach in the provision of palliative care services”; (2) “Interprofessional Training in Gynecologic Oncology Palliative Care”; (3) “Simulation-Based Interprofessional Training in Gynecologic Oncology Palliative Care”. In the research, the students stated that
\end{abstract}

1 Hacettepe Üniversitesi, Hemşirelik Fakültesi, Doğum-Kadın Hastalıkları Hemşireliği A.D., Ankara, Türkiye

2 Atıım Üniversitesi, Sağlık Bilimleri Fakültesi, Hemşirelik Bölümü, Ankara, Türkiye

Sorumlu Yazar / Corresponding Author: Fatma USLU ŞAHAN, e-mail: fatma.uslu@hacettepe.edu.tr

Geliş Tarihi / Received: 03.05.2019, Kabul Tarihi / Accepted: 09.09.2019 
understood the importance of teamwork and interdisciplinary training in palliative care; in order to learn the roles and responsibilities of other professions, to work as a team, and to provide patient safety and patientcentered care, it is necessary to have a simulation-based interprofessional training. The students emphasized the necessity of simulation-based interprofessional training in undergraduate education curricula. It was determined that students had the opportunity to improve their mistakes, correct their mistakes/errors and realized their professional professionalism with simulation applications.

Conclusion: It is recommended that trainers and students be encouraged and integration into undergraduate education curricula to use interprofessional simulation practices in the training of health professionals.

Keywords: Nursing research; gynecology; cancer; qualitative research; palliative care; healthcare team; simulation training.

\section{GíRIŞ}

Jinekolojik kanserler özellikle Türkiye gibi gelişmekte olan ülkelerde kanser yükünün önemli bir kısmını oluşturmakta ve bu ülkelerde kadınlarda önemli bir mortalite ve morbidite nedeni olabilmektedir $(1,2)$. Bu açıdan günümüzde tedaviye yanıt vermeyen ilerlemiş ve tekrarlayan jinekolojik kanser vakalarında palyatif bakıma yönelik ilgi artmıştır (1-3). Palyatif bakım, "yaşamı tehdit edici hastalıklara eşlik eden sorunlar yaşayan hasta ve ailelerin, fiziksel, psikososyal ve manevi (spiritüel) problemlerini erken tanılama, değerlendirme, tedavi ederek acı çekmelerini azaltma ya da önleme ve böylece yaşam kalitelerini artırma amacı olan bir yaklaşım' olarak tanımlanmaktadır (4). Bu yaklaşım hastaya tanı konulduğu andan itibaren başlamakta, ölüme kadar küratif tedavi ile birlikte devam etmekte, ölüm sonrası yas sürecinde aile ve diğer bakım vericileri destekleyen bakımla sona ermektedir $(1,3,4)$. Palyatif bakımın jinekolojik kanserli hastalar açısından önemini dikkat çekmek amacıyla Jinekoloji Onkoloji Derneği [Society of Gynecologic Oncology (SGO)] 2013 y1lında "jinekolojik onkolojide kaçınılması gereken beş test/prosedür" ile ilgili kanıta dayalı önerileri yayınlamış ve ilerlemiş ya da nüksetmiş jinekolojik kanserli kadınlarda temel palyatif bakım için gecikilmemesini ve uygun olduğunda özel palyatif bakım için refere edilmesini vurgulamıştır (5).

Geçtiğimiz yıllarda palyatif bakım hizmeti Türkiye'de kanser kontrol faaliyetlerinin en zayıf parçasını oluştururken, 2009-2015 ulusal kanser kontrol programının en önemli yapı taşlarından biri olarak kabul edilmiştir $(3,6)$. Sağlık Bakanlığı Kanserle Savaş Dairesi Başkanlığı tarafından 2009 yılında Palyatif Bakım Programı oluşturulmuş ve 2011 yılında ise kanser dahil olmak üzere kronik hastalığ palyatif bakım hizmetlerini kapsayan PALLİA-TÜRK adında bir proje (2011) hazırlanmıştır $(1,3,6)$. Bu proje ile birlikte, palyatif bakım hizmetlerinin yürütülmesi için doktor, hemşire, sosyal hizmet ve beslenme ve diyetetik uzmanlarının yer aldığı mesleklerarası palyatif bakım ekipleri oluşturulmuş ve hizmete açılan palyatif bakım ünitelerinde bu ekiplerin istihdam edilmesi sağlanmıştır (6). Ancak Türkiye'de palyatif bakım hizmetlerinin kaliteli bir șekilde sürdürülmesi ve kalitesinin arttırılmasında bazı engeller ile karşılaşılmaktadır $(1,3,6,7)$. Çünkü palyatif bakım ekibi içerisinde yer alan sağlık profesyonelleri lisans eğitimleri süresince birlikte çalışabilen ekip üyeleri olarak yetiştirilmemekte ve mesleklerarası öğrenim deneyimi sağlayan bir palyatif bakım eğitimi almamaktadır. Palyatif bakıma yönelik hem öğrencilere hem de sağlık profesyonellerini içeren eğitimler farklı kurum ve kuruluşlar tarafından düzenlenmektedir. Ancak bu eğitimler uygulama olmadan teorik eğitimle sinırlı kalmaktadır $(7,8)$. Türkiye'de hemşirelik öğrencileri ile yapılan bir çalışmada, öğrencilerin \%64,2'si palyatif bakım hakkında bilgi almadığını (9), Tıp Fakültesi öğrencileri ile yapılan başka bir çalışmada ise öğrencilerin çoğunluğu $(\% 51,9)$ daha önce palyatif bakım konusunu duymadıklarını belirtmişlerdir (10). Sağlık profesyonelleri ile yapılan çalışmalarda da katılımcıların çoğunluğunun (\%52,364,2) palyatif bakım konusunda bilgisi olmadığ vurgulanmaktadır $(1,8)$. Lisans müfredatı içerisinde palyatif bakım konusuna yeterince yer verilmemesi, palyatif bakımın gelişmesinde önemli bir engeldir (8). Bu nedenle sağlı profesyonellerinin palyatif bakım konusunda bilgi ve becerilerini geliştirebilmek, farkındalıklarını arttırabilmek için lisans eğitimleri içerisinde nitelikli mesleklerarası palyatif bakım eğitimine ihtiyaç vardır.

Mesleklerarası palyatif bakım eğitimi programları palyatif bakım konusunda yeterliliklerin kazanılması için temel eğitim programlarından biridir (11-14). Mesleklerarası eğitim, sosyal hizmet ve sağlık alanlarında, çalışacak iki ya da daha fazla sayıda uzmanın/öğrencinin birlikte ve birbirleriyle etkileşimli bir şeklide çalışmalarına yönelik öğrenim biçimi olarak tanımlanmaktadır (15). Mesleklerarası eğitim, sağlık profesyonellerinin kendi uzmanlık alanlarında edindikleri bilgileri, mesleklerarası bir yaklaşımla analiz edip, bunların mesleklerarası ekip tarafindan kavramasına ve bu bilgilerin birleştirilerek entegre edilmesine zemin hazırlamaktadır $(15,16)$. Bu şekilde oluşan bir ekip ile sorunların tek bir disiplinden oluşan ekiplerden daha etkili çözülebileceği ön görülmektedir (13,16-18). Mesleklerarası eğitimde ise problem çözme, başarılı iletişim, bilgi ve becerinin öğretilmesi ve geliştirilmesi, hasta merkezli uygulama ve ekip işbirliği ile çalışma gibi yetkinliklerin birçoğu $(15,17,18)$ eğitimde yeni ve teknolojik bir yöntem olan simülasyon kullanımı ile geliştirilebilir (18-21).

Simülasyon ile geliştirilmiş mesleklerarası eğitim, gelecekte birlikte çalışacak sağlık öğrencilerinin eğitimi için önerilmektedir (17-20,22,23). Simülasyon ile geliştirilmiş mesleklerarası eğitim, bütünsel yaklaşım ve dönüştürücü öğrenme yoluyla diğer meslekler hakkında anlayışı arttırmak için tasarlanmış senaryolar ile simülasyon yöntemlerinin kullanımı olarak tanımlanmaktadır (18). Amaç; bakımın kalitesini ve güvenliğini geliştirmek, diğer meslekleri anlamak ve saygı göstermek, ilişki kurmak, işbirliği ve bilgi paylaşımı yapmak, problem çözme becerilerini geliştirmek ve sağlık meslekleri arasındaki iletişimi ilerletmektir $(18,19,24)$. Simülasyon ile geliştirilmiş mesleklerarası eğitim ile ekip çalışmasını geliştirebilecek gerçekçi bir eğitim yaklaşımı, standartlaştırılmış deneyim 
$(11,16-18,21,23,25,26)$ ve hatalardan öğrenme sağlanarak hastaların zarar görmesi önlenmeye çalışılmaktadır $(18,20,21,25)$. Brown ve ark. (27) ve Jimenez ve ark. (22) simülasyona dayalı mesleklerarası eğitimin lisans öğrencilerinin ekip içerisinde kendi rollerini ve diğer ekip üyelerinin rollerini anlamada etkili olduğunu belirtmişlerdir. Cunningham ve ark. (28) simülasyona dayalı mesleklerarası eğitimin lisans öğrencilerin profesyonel ekip çalışması becerilerinin arttığını, mesleki rol ve sorumlulukları keşfettikleri ve tedavi becerilerinde daha fazla güvene sahip olduklarını belirlemişlerdir. $\mathrm{Bu}$ yaklaşım ile hatalardan öğrenme sağlanarak hastaların zarar görmesi önlenmeye çalışılmaktadır $\quad(18,20,21,25)$. Literatürde sağlık profesyonellerine $(13,29)$ ve öğrencilere $(11,26,30,31)$ yönelik mesleklerarası palyatif bakım eğitiminde simülasyon yönteminin etkinliği vurgulanmaktadır. Prelock ve ark. (14) mesleklerarası palyatif bakımda işbirliğinin sağlanmasına yönelik simülasyona dayalı mesleklerarası eğitim sonrasında öğrenciler, palyatif bakım ile ilk defa karşılaştıklarını ancak mutlaka eğitimleri içerisinde yer alması gerektiğini belirtmişlerdir. Palyatif bakım hizmet sunumunda yaşanan sorunlara çözüm getirebilmek için yapılacak en önemli adımlardan birisi lisans eğitimi içerisine simülasyona dayalı mesleklerarası palyatif bakım eğitiminin entegre edilmesidir. Mesleklerarası simülasyon uygulamaları ile kanser hastası ve ailesine palyatif bakım hizmeti sunumunun gerçekleştirilmesi, profesyonel bir palyatif bakım ekibi olarak, sürecin en iyi şekilde yönetilebilmesi için deneyim kazanımını sağlamaktadır (11,14,24,30,31). $\mathrm{Bu}$ araştırmada simülasyona dayalı mesleklerarası eğitim ile hem teorik hem de uygulamalı eğitimi kapsayan müdahaleler sonrasında, gerçekleştirilen eğitim müdahalesi değerlendirilmiştir. Araştırmada, lisans öğrencilerine yönelik eğitim müdahalesi çalışması yapılarak, jinekolojik onkoloji palyatif bakımda simülasyona dayalı mesleklerarası eğitime yönelik öğrencilerin görüş, düşünce ve önerilerinin belirlenmesi amaçlanmıştır. Lisans programlarında palyatif bakımın mesleklerarası eğitimine yönelik ilk araştırma niteliğinde olan bu çalışmanın konu ile ilgili gereksinimi sağlayacak, gelecek araştırmalara ve eğitimlere yol gösterici olacağı düşünülmektedir.

\section{GEREÇ VE YÖNTEMLER Araştırmanın Tipi}

$\mathrm{Bu}$ araştırma mesleklerarası simülasyon eğitiminin öğrencilerin jinekolojik onkoloji palyatif bakım yeterliliklerine, disiplinlerarası eğitim algısına ve ekip çalışması tutumlarına etkisini belirlemek amacıyla (randomize kontrol müdahale araştırması ile nitel araştırma tasarımlarından biri olan yorumlayııı fenomenolojik yaklaşımın yer aldığı) karma yöntem ile yapılan doktora tez çalışmasının nitel bölümünü içermektedir. Fenomenolojik araştırmalar insan davranışlarını, olguya ilişkin yaşadığı deneyimleri, bulunduğu durumu nasıl algıladığ1 ve bu durumdan nasıl etkilendiğini çok yönlü bir şekilde ortaya çıkarmayı sağlamaktadır (32). Yorumlayıcı fenomenolojik araştırmada ise, yaşanmış olan deneyimin detaylı incelenmesi, deneyimin anlamının katılımcıya etkisi ve katılımcıların deneyimi nasıl anlamlandırdıkları üzerinde durmaktadır (33). Bu doğrultuda araştırma, jinekolojik onkoloji palyatif bakımda simülasyona dayalı mesleklerarası eğitime yönelik öğrencilerin görüş, düşünce ve önerilerinin belirlenmesi amacıyla nitel araştırma yöntemlerinden yorumlayıcı fenomenolojik yaklaşım kullanılarak gerçekleştirilmiştir.

\section{Evren ve Örneklem}

Araştırmanın evrenini bir üniversitenin Hemşirelik Fakültesi'nde (18), Beslenme ve Diyetetik Bölümü’nde (18), Sosyal Hizmet Bölümü'nde (18) öğrenim gören üçüncü sınıf öğrencileri ile Tip Fakültesi'nde öğrenim gören dördüncü sınıf öğrencileri'nden (9) “Mesleklerarası Jinekolojik Onkoloji Palyatif Bakım Eğitimi" alarak yüksek geçerlikte simülasyon (simülasyon uygulamalarında gözleri ve göğüs kafesleri hareket edilebilen, invaziv uygulamalar yapılabilen, fiziksel değerlendirmelere cevap verebilen, manüel olarak senaryo doğrultusunda yönlendirilebilen mankenlerin kullanıldığ 1 uygulamalar) ve/veya hibrit simülasyon (prosedürel ve operatif becerileri uygulamaya izin veren hasta simülasyonu amacı ile seçilerek eğitilmiş sıradan kişilerin ve simülatör kombinasyonun kullanıldığ uygulamalar) uygulamalarını tamamlayan öğrenciler oluşturmaktadır. Bu öğrencilerin, araştırmanın nicel bölümüne başlamadan önce tabakalandırma (fakülte/bölümlere göre) ve bloklama (her tabakadan eşit öğrenci içerecek) yöntemi kullanılarak üç farklı simülasyon grubuna [yüksek geçerlikte simülasyon (YGS) (21 kişi), hibrit simülasyon (HS) (21 kişi), yüksek geçerlikte simülasyon ve hibrit simülasyon (YGS+HS) (21 kişi)] randomizasyonu gerçekleştirilmiştir. Randomizasyon sonrasında "Mesleklerarası Jinekolojik Onkoloji Palyatif Bakım Eğitimi"'ni tamamlamış ve simülasyon eğitimlerine katılmışlardır. Öğrenciler ile araştırmacıların ders kapsamında ilgisi ve bağımlı bir ilişkisi bulunmamaktadır.

Araştırmanın örneklemi, niteliksel verilerin toplandığ 1 amaçlı örnekleme yöntemlerinden maksimum çeşitlilik örnekleme ile elde edilmiştir. Maksimum çeşitlilik örnekleme yönteminin kullanılma nedeni; örnekleme dâhil her durumun kendine özgü boyutlarının ayrıntılı bir biçimde tanımlanmasını sağlamaktır (32). Collins ve ark. (34) odak grup görüşmeleri için gereken örneklem sayısının en az altı-12 arasında olması gerektiğini ve doygunluğa ulaşmak için üç-beş odak grubun yeterli olacağını belirtmişlerdir. Bu bilgiler ışığında her bir odak grup görüşmesi yedi öğrenciden oluşmuş (her bir fakülteden/bölümden en az birer öğrenci alınmış) ve dört odak grup görüşmesi gerçekleştirilmiştir. Araştırmaya katılmaya gönüllü olan 28 öğrenci (sekiz hemşirelik, sekiz beslenme ve diyetetik, sekiz sosyal hizmet ve dört tıp öğrencisi) araştırmanın örneklemini oluşturmuştur.

\section{Verilerin Toplanması}

Fenomenolojik yaklaşım araştırmalarında veri kaynaklarını, belirlenen olguyu yaşayan ve bu olguyu dişa vurabilecek bireyler ya da gruplar oluşturur. Bu çalışmalarda araştırmacılar bireylerin söylediklerine ilişkin bireysel duygu, düşünce ve perspektiflerin ortaya çıkarılması ve yorumlanmasını amaçlar (32). Bu araştırmada veri toplama tekniği olarak odak grup görüşme tekniği kullanılmıştır. Araştırmada dört odak grup görüşmesi gerçekleştirilmiş ve her bir odak grup iki Hemşirelik Fakültesi öğrencisi, bir Tip Fakültesi 
öğrencisi, iki Beslenme ve Diyetetik Bölümü öğrencisi, iki Sosyal Hizmet Bölümü öğrencisi olmak üzere yedi kişiden oluşmuştur.

Odak grup görüşmeleri yalnızca öğrenciler ve bir araştırmacıların bulunduğu, araştırmanın yapıldığ 1 kurumun Mesleklerarası Simülasyon Merkezi ve Değerlendirme Merkezi'nde yer alan boş bir odada yapılmıştır. Görüşmeler yaklaşık bir saat sürmüş olup ses kayıt cihazı ile kayıt edilmiştir. Öğrencilerden alınan verilerin tekrar edildiği noktaya gelindiğinde odak grup görüşmeleri sonlanmıştır. Görüşmeler esnasında araştırmacılar tarafindan notlar alınmış ve ses kayıt cihazı kullanılmıştır.

\section{Uygulama Süreci}

Araştırmanın uygulaması Nisan 2017-Mayıs 2017 tarihleri arasında gerçekleştirilmiştir. Araştırmanın evreninde yer alan öğrenciler (Hemşirelik (18) ve Tıp Fakültesi (dokuz), Beslenme ve Diyetetik Bölümü (18) ve Sosyal Hizmetler bölümü (18) öğrencileri) meslekleraras1 jinekolojik onkoloji palyatif bakım uygulamaları konusunda bilgi düzeylerini arttırılması amacıyla 16 saati (iki gün) kapsayan "Jinekolojik Onkolojiye Yönelik Mesleklerarası Palyatif Bakım Eğitimi” katılmışlardır. Eğitim programının içeriğin kapsam geçerliliği için jinekolojik onkoloji ve palyatif bakım konusunda uzman üç kişiden görüş alınmış ve gerekli düzenlemeler yapılarak eğitime son şekli verilmiştir. Eğitim programının son aşamasında serviks kanseri bir hastanın palyatif tedavi ve bakımını mesleklerarası yaklaşım ile planlamaya yönelik vaka tartışması yapılmıştır. Eğitim programının tamamlanmasının ardından öğrenciler hastanede palyatif tedavi alan over kanseri bir hastanın taburculuğunun planlanmasına yönelik oluşturulan senaryo ile simülasyon uygulamalarına ekip olarak katılmışladır. Her bir ekip bir hekim, iki hemşire, iki sosyal hizmet ve iki beslenme ve diyetetik öğrencilerinden oluşmaktadır.

YGS uygulaması için yüksek geçerlikte simülasyon mankeni kullanılmıştır. HS uygulaması için araştırmanın yapıldığı kurumun Tıp Fakültesi Tıp Eğitimi ve Bilişimi Anabilim Dalı Standart Hasta Programı'na kayıtlı standart hasta ile görüşülmüştür. Simülasyon mankeni ve standart hasta senaryo doğrultusunda (Simülasyon mankeninin/standart hastanın abdomenine $10 \mathrm{~cm} \times 5 \mathrm{~cm}$ boyutunda palpe edilebilen kitle yerleştirilmiş ve abdomen manken karın derisi ile kaplanmıştır. Mulaj tekniği ile mankenin/standart hastanın kolu ve el üzerine morluklar ve abdomeninde $15 \mathrm{~cm}$ uzunluğunda (uzunlamasına) skar dokusu oluşturularak pansuman malzemeleri ile kaplanmıştır.) hazırlanmıştır. Simülasyon uygulamaları araştırmanın gerçekleştirildiği kurumun Mesleklerarası Eğitim ve Simülasyon Merkezi'nde gerçekleştirilmiş ve uygulamalar iki hafta sürmüştür.

Simülasyon uygulamaları tamamlandıktan sonra araştırmaya katılmayı kabul eden öğrenciler ile iletişime geçilmiştir. Her bir odak grupta yer alan öğrencilerin uygun oldukları tarih ve saat belirlenerek öğrenciler odak grup görüşmelerinin yapılacağı zaman hakkında bilgilendirilmiştir.

Araştırmanın verileri öğrencilerin tanıtıcı özellikleri bilgi formu ve yarı yapılandırılmış odak grup görüşmesi soru yönergesi ile toplanmıştır. Öğrencilerin tanıtıcı özellikleri bilgi formunda; öğrencilerin yaşını, cinsiyetini, bölümünü/fakültesini ve hangi simülasyon uygulama grubunda yer aldığını belirlemeye yönelik sorular yer almaktadır. "Yarı Yapılandırılmış Odak Grup Görüşmesi Soru Yönergesi" ilgili literatür dikkate alınarak ve anlaşılabilirliği ve kullanılabilirliği açısından üç uzman kişiden görüş alınarak oluşturulmuştur. $\mathrm{Bu}$ yönerge aşağıdaki sorulardan oluşmaktadır.

1. Palyatif bakım hizmetlerinin ekip yaklaşımı ile sunumu konusunda ne düşünüyorsunuz?

2. Mesleklerarası Jinekolojik Onkoloji Palyatif Bakım Eğitimi'nin farklı meslekler ile verilmesi konusunda düşünceleriniz nelerdir?

3. Simülasyona dayalı mesleklerarası eğitimin daha etkili ve verimli olabilmesi için önerileriniz nelerdir?

4. Simülasyon uygulamalarının, teorik eğitim üzerine etkisini nasıl değerlendiriyorsunuz?

\section{Araştırmanın Etik Boyutu}

Araştırmanın etik açıdan uygunluğunun değerlendirilmesi için araştırma öncesi araştırmanın gerçekleştirildiği kurumun etik kurulundan etik açıdan uygun bulunduğuna dair onay yazısı alınmıştır (26 Temmuz 2016 tarih ve 16969557/793 sayılı yazı). Araştırmanın uygulanabilmesi için ilgili fakülte/bölümlerden yazılı izin alınmıştır. Araştırmaya katılmayı kabul eden ögrencilerden yazılı aydınlatılmış onamları alınmıştır.

\section{Nitel Verilerin Analizi}

Araştırma verilerin analizinde, tümevarım yaklaşımı ve içerik analizi kullanılmıştır. Nitel verilerin daha yakından incelenmesini ve bu verileri açıklayan kavramlara ve temalara ulaşılmasını sağlayan içerik analizinde, toplanan veriler önce kavramlaştırılmış ve ortaya çıkan kavramlara göre mantıklı bir biçimde düzenlenerek, veriyi açıklayan tema ve alt temalar saptanmıştır (32). Araştırmacılar tarafından ortak tartışma ve fikir alışverişiyle transkriptlerin çözümlemeleri ve analizleri yapılmış, üç tema, dört alt tema ortaya çıkarılmıştır.

Araştırmanın verileri dört aşamada analiz etmiş̧tir.

1.Aşama (Transkripsiyon ve Veri Doğrulama): Görüşmeler esnasında araştırmacılar tarafından notlar alınmış ve ses kayıt cihazı kullanılmıştır. Veri analizi sürecinde ilk olarak elde edilen ve ses kayıt cihazı ile kayıt altına alınan nitel veriler araştırmacılar tarafından yazılı doküman haline getirilmiştir. Transkripsiyon görüşme sonrası ilk 24 saat içerisinde gerçekleştirilmiş, görüşmelerin transkripsiyonundan 40 sayfa veri elde edilmiştir. Araştırmacılar tarafından iki kez tekrar dinlenerek yapılan transkripsiyon kontrol edilmiştir.

2.Aşama (Verilerin Kodlanması): Araştırmacılar elde ettiği bilgileri inceleyerek, anlamlı bölümlere ayırmaya ve her bölümün kavramsal olarak ne anlam ifade ettiğini bulmaya çalışmıştır. Kodlama sürecinden önce nitel veriler araştırmanın amacı ve kavramsal çerçevesi dikkate alınarak araştırmacılar tarafindan birkaç defa okunmuştur. Kodlama aşamasında nitel verilerin işlenmesi sırasında ortaya çıkan kavramlara göre kodlama yapılmıştır. Araştırma verilerinden elde edilen 16 kod tümevarımcı bir yaklaşımla ortaya çıkarılmıştır.

3.Aşama (Temaların Bulunması): Ortaya çıkan kodlardan yola çıkarak verileri, genel düzeyde açıklayabilen ve kodları belirli kategoriler altında toplayabilen temalar belirlenmiştir. Temalar oluşturulurken anlamlı bir bütün oluşturup oluşturmadığı ve elde edilen nitel verileri anlamlı bir biçimde açıklayabilmesi dikkate alınmıştır. 
4.Așama (Verilerin Kodlara ve Temalara Göre Düzenlenmesi ve Tanımlanması): İkinci aşamadaki ayrıntılı kodlama ve üçüncü aşamadaki tematik kodlama sonucunda, araştırmacılar topladıkları verileri, kendi görüş ve yorumlarına yer vermeden ve toplanan bilgileri işlenmiş bir biçimde hazırlamıştır. Araştırmanın bulgularına öğrencilerin görüşlerini, düşüncelerini ve önerilerini en iyi vurgulayan/tanımlayan ifadelerden doğrudan alıntılar yapılmıştır.

\section{Araștırmanın Geçerliği ve Güvenirliği}

Araştırmanın geçerliği ve güvenirliği için Creswell ve Miller (35) aktardığı ölçütler dikkate alınmıştır. Bu nedenle iç geçerlik yerine inandırıcılık, dış geçerlik yerine aktarılabilirlik kavramları kullanılmıştır. İnandırıcılık; araştırma sonuçlarının açık, tutarlı ve başka araştırmacılar tarafından teyit edilebilir olmasıdır $(32,35)$. Öğrenciler ile yapılan odak grup görüşmeleri soruları rahatlı ile cevaplayabilecekleri bir ortamda gerçekleştirilmiş, öğrencilerin cevapları araştırmacı tarafından geribildirimler ile teyit edilmiştir. Araştırmanın sonuçları, öğrencilerin ifadelerinden yapılan doğrudan alıntılar ile birlikte verilmiştir. Alıntıların, belirlenen tema ve alt temalarla ilişkili ve açıklayıcı nitelikte olmasına dikkat edilmiştir. Aktarabilirlik; araştırma sonuçlarının genellenemeyeceği, ancak bu tür ortamlara sonuçların uyarlanabileceğine ilişkin yargılara ulaşılması ve denenceler oluşturulması anlamına gelmektedir (32,35). Araştırmadan elde edilen nitel bulgular, benzer araştırma bulgularıyla karşılaştırma yapılabilecek düzeyde ayrıntılı olarak verilmiştir.

Nitel araştırmada güvenirlik; nitel araştırmalarda 'iç güvenirlik" yerine 'tutarlık', ' dış güvenirlik' yerine "teyit edilebilirlik" kavramları kullanılmaktadır (35). Tutarlık; olay ve olguların değişkenliğini kabul etmek ve bu değişkenliği araştırmaya tutarlı bir biçimde yansitabilmektir (32,35). Araştırmacılar odak grup görüşmeleri sırasında her bir gruba benzer bir yaklaşım ile soruları yöneltmiş ve kayıt altına almıştır. Elde edilen nitel verilerin analiz sürecinde ise nitel araştırma konusunda eğitimli ve deneyimli iki araştırmacıdan destek alınmıştır. Araştırmanın nitel verileri doğrudan alıntılar yapılarak sunulmuştur. Teyit edilebilirlik; araştırmacının ulaştığı sonuçları topladığı verilerle sürekli olarak teyit etmesi ve bu çerçevede okuyucuya mantıklı bir açıklama sunabilmesidir $(32,35)$. Bu araştırmada teyit edilebilirlik için, araştırmacılar tarafindan ulaşılan sonuçlar açık ve anlaşılır şekilde okuyucuya aktarılmıştır. Araştırma nitel sonuçları, yapılan benzer araştırmalarla karşılaştırılmış, literatür ile desteklenerek tartışma bölümünde açıklanmıştır.

\section{BULGULAR}

Araştırmada öğrencilerin yaş ortalaması 22,35 $\pm 2,80$, çoğunluğu kadındır $(\% 67,9)$. Öğrencilerin yedisi yüksek geçerlikte simülasyon, 14'ü hibrit simülasyon ve yedisi hem yüksek geçerlikte simülasyon hem de hibrit simülasyon uygulamasına katılmıştır.

Öğrenciler ile yapılan görüşmeler sonucunda elde edilen bulgulardan üç tema ve dört alt tema belirlenmiştir (Tablo 1).
Tablo 1. İçerik analizi sonucunda oluşturulan temalar ve alt temalar

\begin{tabular}{|l|l|}
\hline \multicolumn{1}{|c|}{ Tema } & \multicolumn{1}{c|}{ Alt Tema } \\
\hline $\begin{array}{l}\text { 1.Palyatif bakım hizmeti } \\
\text { sunumunda ekip } \\
\text { yaklaşımı }\end{array}$ & 1.1.Palyatif bakımda ekibin önemi \\
\hline $\begin{array}{l}\text { 2. Mesleklerarası } \\
\text { Jinekolojik Onkoloji } \\
\text { Palyatif Bakım Eğitimi }\end{array}$ & $\begin{array}{l}\text { 2.1.Palyatif bakım eğitiminde } \\
\text { mesleklerarası yaklaşımın önemi } \\
\text { 2.2.Mesleklerarası Palyatif Bakım } \\
\text { Eğitimi'nin daha etkili ve verimli } \\
\text { olmasına yönelik öneriler }\end{array}$ \\
\hline $\begin{array}{l}\text { 3.Simülasyona Dayalı } \\
\text { Mesleklerarası } \\
\text { Jinekolojik Onkoloji } \\
\text { Palyatif Bakım Eğitimi }\end{array}$ & $\begin{array}{l}\text { 3.1.Simülasyon kullanımının } \\
\text { eğitim üzerine etkisi }\end{array}$ \\
\hline
\end{tabular}

Öğrencilerin ifadeleri verilirken, öğrencilerin kimliklerini gizlemek adına, ifadenin ardından parantez içerisinde öğrencinin numaras1, fakülte/bölümü ve öğrencinin bulunduğu simülasyon uygulama grubu verilmiştir. Örneğin; 25 nolu öğrenci, Beslenme ve Diyetetik Bölümü, Yüksek geçerlikte simülasyon ve Hibrit simülasyon (YGS+HS).

Tema 1. Palyatif bakım hizmeti sunumunda ekip yaklaşımı

\section{Alt Tema 1.1. Palyatif bakımda ekibin önemi}

Öğrenciler farklı uzmanlık alanlarından oluşan palyatif bakım konusunda eğitim almış bir ekibin, palyatif bakımın hedeflerinin gerçekleştirilebilmesi için önemli olduğunu belirtmişleridir. Öğrenciler ekip yaklaşımının hasta merkezli bakımı sağladığını hastanın kendisine tedavi sağlayan ekibe güveni ve hasta güvenliği açısından önemli olduğunu vurgulamışlardır.

"Ekip olarak koordine bir şekilde ve mutlaka bu alanda eğitim almalar gerekiyor.” (25 nolu öğrenci, Beslenme ve Diyetetik Bölümü, YGS+HS)

"Kesinlikle ekip hizmeti olmall, herkesin uzmanlık alanı farklı bence bunu uygulamalarımızda da çok net gördük. Herkes kendi uzmanlı alanı ile ilgili değerlendirme yaparken sonuca birlikte ulaşlyor." (24 nolu ögrenci, Hemşirelik Fakültesi, YGS+HS)

"...hastayı her yönden gözlemliyoruz ve hepimiz hastanın durumundan haberdar oluyoruz, gözden bir şey kaçırma ihtimali çok düşük hasta için..."(22 nolu ögrenci, Tip Fakültesi, YGS+HS)

Tema 2. Mesleklerarası Jinekolojik Onkoloji Palyatif Bakım Eğitimi

Alt Tema 2.1. Palyatif bakım eğitiminde mesleklerarası yaklaşımın önemi

Öğrenciler eğitimde mesleklerarası yaklaşımın diğer mesleklerin rol ve sorumluluklarını öğrenebilmek, birlikte çalışabilmek ve hasta ve ailesine bütüncül bir bakış açısı ile palyatif bakım hizmeti sunabilmek açısından önemli olduğunu belirtmişlerdir. Mesleklerarası eğitimin etkisi ile hem kendilerinin üzerinden fazladan oluşabilecek iş yükünü kaldırabileceklerini ve birbirlerinin eksik kalan yönlerini tamamlayabileceklerini hem de hasta ve yakınlarına daha iyi hizmet sunulabileceğini belirtmişlerdir. Ayrıca öğrenciler lisans eğitimleri süresince mesleklerarası yaklaşımın eğitimlerinde yer almadığını ancak mutlaka lisans eğitiminde yer alması gerektiğini vurgulamışlardır. 
"Zaten farklı alanlarda çalışıyoruz. Ekip ile çalışmaların artması gerekiyor ki biz bu sürece alışalım, diğer meslek grubundan benim hemşirelikten, diyetisyenlikten, tıptan ögrendiğim çok fazla şey oluyor ve faydall. Tüm sürecin bütününü, bütünsel olarak bakıp yararl olabilmek için gerekli..." (27 nolu ögrenci, Sosyal Hizmet Bölümü, YGS)

"IŞs yükünü azaltıyoruz aslında, hastayı dört bir yandan inceliyoruz. Gerçekten birbirimiz üzerinden çok yük kaldırlyoruz..."(2nolu öğrenci, Hemşirelik Fakültesi, YGS)

"Birbirimiz eksiklerini tamamlayabilmemiz için eğitim bence bu şekilde olmalı.” (14 nolu öğrenci, Sosyal Hizmet Bölümü, HS)

"Üniversitelerde halen böyle bir eğitim yok. Üniversitelerde ileride beraber çalışacağımız mesleklerin görevlerinin anlatılması gerekiyor... Tek palyatif bakım değil her yerde multidisipliner çalışmayı ögrenmemiz gerekiyor." (26 nolu ögrenci, Beslenme ve Diyetetik Bölümü, YGS+HS)

"Zorunlu bir ders kapsamında böyle bir ders konulabilir belki... İleride sağlık alanında çalışabilecek meslek üyelerinin lisans müfredatına mutlaka konulması gerekiyor." (12 nolu öğrenci, Tip Fakültesi, YGS+HS)

Alt Tema 2.2. Mesleklerarasi Palyatif Bakım Eğitimi’nin daha etkili ve verimli olmasına yönelik öneriler

Öğrenciler eğitimin daha etkili ve verimli olabilmesi için eğitim ve simülasyon uygulamalarından sonra klinik uygulama yapılabileceğini, sağlık profesyonellerinin de eğitiminin mutlaka simülasyon uygulamasına yer verilmesi gerektiğini belirtmişlerdir. Öğrenciler eğitim içerisine, özellikle simülasyon uygulamasında önce palyatif bakım tedavisi alan hasta ve/veya ailesinin tecrübelerini paylaşabilecekleri bir dersin ya da gerçek yaşam deneyimlerinden oluşan bir video gösterimin eğitim içeriğine eklenebileceğini belirtmişlerdir.

“...bu eğitimin mutlaka hastane ortamında bir de stajı olması gerektiğini düşünüyorum. Eğitim olarak uygulamalı eğitim olabilir." (13 nolu öğrenci, Sosyal Hizmet Bölümü, HS)

"Ekip olarak bu ders seçmeli ders olsa, bide ekip olarak bu dersi alabilsek, simülasyondan sonra staj programı olsa..." (1 nolu öğrenci, Tip Fakültesi, YGS)

"Birde mesela şey olabilirdi. Palyatif bakım alan bir hasta veya hasta yakını gelip kendi görüşlerini vs. En azında simülasyon uygulamasına girmeden önce palyatif bakıma daha aşina olabilirdik. Mesela diyetisyen geldi rolünü anlattı hasta ve yakınlarının tecrübelerini de dinlemek isterdik." (12 nolu ögrenci, Beslenme ve Diyetetik Bölümü, $H S)$

“...Gelmesi mümkün olmasa bile yakını gelebilir ya da bir video olabilir. Ekip ne yapıyor. Gerçek bir ekip yaklaşımı ile ilgili.” (9 nolu öğrenci, Hemşirelik Fakültesi, HS)

Tema 3. Simülasyona Dayalı Mesleklerarası Jinekolojik Onkoloji Palyatif Bakım Eğitimi Alt Tema 3.1. Simülasyon kullanımının eğitim üzerine etkisi

Öğrenciler simülasyon uygulamaları ile teorik eğitimde öğrendikleri daha iyi pekiştirdiklerini, simülasyon uygulamaları ile yanlışlarını/hatalarını düzeltme firsatı bulduklarını, mesleki profesyonelliklerinin farkına vardıklarını vurgulamışlardır. Özellikle ilk kez simülasyon uygulamasına katılan öğrenciler kendi mesleki eğitimlerinde de simülasyon uygulamasının olması gerektiğini vurgulamışlardır.

“...teori tabi ki ama ben uygulamadan sonra hastanın kizl bana sorular sorunca ve bende yanitlayabilince aslında neden orada olduğumu daha iyi öğrendim." (14 nolu ögrenci, Sosyal Hizmet Bölümü, HS)

"Sadece eğitimden sonra simülasyon uygulamalar olmadan hasta ile karşılaşsaydım, ...şsimdiki kadar kendimi yeterli hissetmezdim. Simülasyonda hastaya yanlış bir şey söylesem bu düzeltebilme firsatım vardl, yanlış olduğunu anlayabildim... ama hastaya yanlış bir şey söyleseydim, o orada yanlış kalacaktı..."(24 nolu ögrenci, Hemşirelik Fakültesi, YGS+HS)

"Profesyonel olarak kendimi çalışlyor hissettim. Seneye mezun olacă̆ım ama ilk defa kendimi sosyal hizmet uzmanı gibi hissettim..."(13 nolu öğrenci, Sosyal Hizmet Bölümü, $H S$ )

Tema 3. Simülasyona Dayalı Mesleklerarası Jinekolojik Onkoloji Palyatif Bakım Eğitimi

Alt Tema 3.1. Simülasyon kullanımının eğitim üzerine etkisi

Öğrenciler simülasyon uygulamaları ile teorik eğitimde öğrendikleri daha iyi pekiştirdiklerini, simülasyon uygulamaları ile yanlışlarını/hatalarını düzeltme fırsatı bulduklarını, mesleki profesyonelliklerinin farkına vardıklarını vurgulamışlardır. Özellikle ilk kez simülasyon uygulamasına katılan öğrenciler kendi mesleki eğitimlerinde de simülasyon uygulamasının olması gerektiğini vurgulamışlardır.

“...teori tabi ki ama ben uygulamadan sonra hastanın kizl bana sorular sorunca ve bende yanitlayabilince aslında neden orada olduğumu daha iyi öğrendim." (14 nolu ögrenci, Sosyal Hizmet Bölümü, HS)

"Sadece eğitimden sonra simülasyon uygulamalar olmadan hasta ile karşılaşsaydım, ...ş̧imdiki kadar kendimi yeterli hissetmezdim. Simülasyonda hastaya yanlış bir şey söylesem bu düzeltebilme firsatım vardl, yanlış olduğunu anlayabildim... ama hastaya yanlış bir şey söyleseydim, o orada yanlış kalacaktı..."(24 nolu ögrenci, Hemşirelik Fakültesi, YGS+HS)

"Profesyonel olarak kendimi çalışlyor hissettim. Seneye mezun olacă̆ım ama ilk defa kendimi sosyal hizmet uzmanı gibi hissettim..."(13 nolu ögrenci, Sosyal Hizmet Bölümü, HS)

\section{TARTIŞMA}

Jinekolojik onkoloji palyatif bakımda simülasyona dayalı mesleklerarası eğitime yönelik öğrencilerin görüş, düşünce ve önerilerini belirlemek amacıyla gerçekleştirilen araştırmada öğrencilerin palyatif bakımda ekip çalışması ve mesleklerarası eğitimin önemini daha iyi anladıklarını, lisans eğitim müfredatlarında mesleklerarası eğitimin ve bu eğitimde simülasyon kullanımının önemini kavradıkları belirlenmiştir. Araştırmada, mesleklerarası eğitimde simülasyon uygulamalarının kullanımının öğrencilerin ekip içerisindeki profesyonel rollerini anlayabilmelerinde etkili bir yöntem olduğu sonucuna ulaşılmıştır.

Amerika Ulusal Konsensus Projesi Kaliteli Palyatif Bakım İçin Klinik Uygulama Rehberi'nde palyatif bakım hizmetlerinin, hastaların bakım kalitesini en üst düzeye çıkarmaya yardımcı olan işbirlikçi ve profesyonelce 
çalışan ekipler tarafından sağlanmasını önermektedir (4). Mesleklerarası simülasyon uygulamaları ile öğrenciler arasında açık iletişim sağlanmakta, bilgi paylaşımı karşılıklı sayg1 ve güveni teşvik edilmekte ve ekip işbirliğine yönelik olumlu tutum gelişimi sağlanmaktadır $(11,19)$. Hastalara bakım verirken etkili bir şekilde ekip işbirliği yapması, hasta bakım sonuçlarının iyileştirilmesine büyük katk1 sağlamaktadır (21,23). Araştırmada mesleklerarası simülasyon uygulamalarından sonra yapılan odak grup görüşmelerinde, öğrenciler palyatif bakım hizmetlerinin istendik hedeflere ulaşılabilmesi için eğitimli ve deneyimli bir ekip yaklaşımı içerisinde verilmesi gerektiğinin önemini belirtmişleridir. Palyatif bakım hizmeti bu şekilde sağlanır ise hasta merkezli bakımın ve hasta güvenliğinin sağlanabileceğini, hasta ve ailesinin ekibe güveninin artabileceğini belirtmişlerdir. Mesleklerarası ekip yaklaşım hasta ve ailelerinin fiziksel, psikososyal ve ruhsal ihtiyaçlarını bütünsel ve kapsamlı bir şekilde değerlendirilmesini sağlayarak palyatif bakımın merkezinde yer almaktadır (12). Mesleklerarası ekip çalışması ile hasta verilerinin ekip içerisinde paylaşılması, karar verme sürecinin kısalmasına katk1 sağlamaktadır $(21,23,26)$. Öğrenciler profesyonel mesleki yaşamlarına başlamadan önce ekip çalışmasına ve işbirlikçi uygulamalara hazır hale gelebilirler ise, hasta güvenliği ve tedavi ve bakıma yönelik hasta sonuçları iyileştirilebilir, hasta memnuniyetinin arttırılabilir (21). Araştırmanın sonucu simülasyon uygulamaları ile öğrencilerin palyatif bakımda ekip yaklaşımının önemini daha iyi kavradıklarını düşündürmektedir.

Mesleki sosyalleşme, eğitim sürecinde başlamaktadır ve öğrenciler sosyalleştikçe kendi disiplinleri ve diğer disiplinler ile işbirlikçi becerileri daha fazla göstermektedir (12,36). Literatürde mesleklerarası işbirliğinin güvenli, etkili ve hasta merkezli bakımı ve sonuçları sağlamak için gerekli olduğu vurgulanmaktadır $(11,15,18-21,23,26,36)$. Baker ve ark. (20) simülasyona dayalı mesleklerarası uygulamaları içeren bir eğitim müfredatının, farklı mesleki gruplarda yer alan öğrenci gruplarının gelişimlerine uygun olduğunu ve öğrencilere birbirleriyle etkileşim kurma firsatı sunduğunu belirtmektedir. Sağlık profesyonellerinin eğitim programlarına, daha güvenli ve daha iyi hasta merkezli bakımı sağlayabilmek için birlikte çalışabilmek üzere hazırlanan mesleklerarası eğitim programlarının müfredata entegre edilmesi önerilmektedir $(12,17,18,22,23,36,37)$. Araştırmada öğrenciler gelecekte birlikte çalışacakları mesleklerin rol ve sorumluluklarını öğrenebilmek ve işbirliğini sağlayabilmek açısından lisans eğitim müfredatı içerisine mutlaka mesleklerarası eğitimin yer alması gerektiğini belirtmişlerdir. Bu eğitim yaklaşımı ile gelecekte işbirliğinin sağlanabileceği ve hasta ve yakınlarına daha iyi hizmet sunulabileceğini belirtmişlerdir. Prelock ve ark. (14) hemşirelik, tıp, konuşma bozukluğu, fizyoterapi, sosyal hizmetler ve beslenme bölümü öğrencilerinde mesleklerarası palyatif bakım ve işbirliğine yönelik eğitimin etkinliğini değerlendirdikleri çalışmalarında, öğrenciler mesleklerarası eğitimin etkisini ve değerini daha iyi anladıklarını ifade etmişlerdir. Fineberg ve ark. (12) çalışmasında tıp ve sosyal hizmetler bölümü öğrencileri mesleklerarası palyatif bakım eğitimine yönelik birbirleri ile açık, dürüst, yansıtıcı ve destekleyici bir ortamda tanışmaktan memnuniyet duyduklarını, kişilerarası etkileşimden fayda gördüklerini, birbirilerini değerli birer kaynak olarak gördüklerini ve birbirlerinden öğrenme firsatı bulduklarını belirtmişlerdir. Jimenez ve ark. (22) mesleklerarası işbirliğinin sağlanabilmesi için öncelikle lisans eğitiminde mesleklerarası eğitime başlanması gerektiğini ve bu eğitimlerin mezuniyet sonrası devam etmesi gerektiğini belirtmişleridir. Hemming ve ark. (37) hemşirelik eğitiminde mesleklerarası eğitimin durumunu belirlemeye yönelik son beş yılın çalışmalarını değerlendirdikleri sistematik derlemelerinde lisans müfradatı içerisinde simülasyona dayalı mesleklerarası eğitimin geliştirilmesi ve bu tarz eğitim programlarının yaygınlaştırılmasının öneminin vurgulamışlardır. Mesleklerarası palyatif bakım uygulamalarının gücü, ekip üyelerinin mesleklere özgü bilgi ve becerilere ortak bir anlayış geliştirmesi ve kullanması, birbirlerini desteklemesi ve hastalar ve aileleri için bakım sağlamaları ile ortaya çıkmaktadır (13). Mesleklerarası eğitimin öneminin giderek artmasına rağmen, palyatif bakım konusunda bu tür öğrenme deneyimini sağlayan az sayıda çalışma vardır (11,13,29-31). Simülasyona dayalı mesleklerarası eğitim müdahaleleri öğrencilerin ekip üyelerinin mesleklere özgü bilgi ve becerilere ortak bir anlayış geliştirmelerine ve kullanmalarına, birbirlerini desteklemelerine ve hastalar ve aileleri için kaliteli palyatif bakım hizmeti sağlayabilmelerine katk1 sağlayabilir. Literatür ile benzer şekilde çalışmamızın sonuçları simülasyona dayalı mesleklerarası eğitimin lisans müfredatına entegre edilmesinin önemini göstermektedir.

Günümüzde geleneksel öğrenme ortamlarından ziyade interaktif öğrenme ortamlarının gerekliliği ön plana çıkmaktadır. Simülasyona dayalı öğrenme, profesyonel ve işbirlikçi beceri kümeleri oluşturmaya yönelik interaktif bir firsat sunmaktadır $(16,18-21,23,36)$. Öğrenciler mesleklerarası eğitimin daha etkili ve verimli olabilmesi için simülasyon uygulamalarının önemini vurgulamışlardır. Bununla birlikte simülasyon uygulamaları ile teorik eğitimde öğrendikleri daha iyi pekiştirdiklerini, simülasyon uygulamaları ile yanlışlarını/hatalarını düzeltme firsatı bulduklarını, mesleki profesyonelliklerinin farkına vardıklarını belirtmişlerdir. Literatürde mesleklerarası eğitimin simülasyon ile desteklenmesi gerektiğini vurgulayan bir çok çalışma bulunmaktadır (16-19,21,22,24,25,31). Saylor ve ark. (31) palyatif bakım eğitiminde simülasyon kullanımının öğrencilerinin yeterliliğini ve özellikle tıp ve hemşirelik öğrencileri arasında işbirlikçi tutumu arttırdığını belirtmişlerdir. Lefebvre ve ark. (16) simülasyona dayalı mesleklerarası eğitimin öğrencilerin disiplinlerarası eğitim algısı, mesleklerarası öğrenmeye hazır oluş durumları, ekip çalışması tutumları ve ekip olarak çalışma becerileri üzerine olumlu etkileri olduğunu belirtmişlerdir Jimenez ve ark. (22) simülasyona dayalı mesleklerarası eğitimin lisans öğrencilerinin ekip içerisinde kendi rollerini ve diğer ekip üyelerinin rollerini anlamada etkili olduğunu belirtmişlerdir. Kotsakis ve ark. (25) sağlık profesyonellerine yönelik düzenlenen simülasyona dayalı mesleklerarası eğitim uygulaması sonrasında katılımcilar, her 4-6 ayda bir simülasyon uygulamalarının yapılmasını ve bu uygulamaların 
uygulamaları daha iyi duruma getirebileceğini belirtmişlerdir. Araştırmanın sonuçları mesleklerarası eğitimin simülasyon uygulamaları ile desteklenmesi gerektiğinin önemini vurgulamaktadır. Mesleklerarası eğitimde simülasyon uygulamalarının kullanımının farklı meslekler arasında köprüler oluşturmaya, etkili bir ekip işbirliğini sağlayarak diğer mesleklerin rollerinin anlaşılmasına ve bilgi kazanımın sağlanmasına katkı sağlayabilir.

Simülasyon mesleklerarası eğitim ile ilgili yetkinlikleri geliştirmek için yenilikçi bir yöntem olarak gösterilmektedir (16-18,20-22,25,31). Bununla birlikte, literatürde, simülasyona dayalı mesleklerarası eğitiminin klinik uygulama ile devam ettirilerek etkinliğinin arttırılabileceği belirtilmektedir (29,38). Araştırmada, öğrenciler simülasyon uygulamaları ile pekiştirilen mesleklerarası eğitimin klinik uygulamalar ile devam edebileceğini belirtmişlerdir. Sicat ve ark. (38) simülasyon uygulamaları olmadan gerçekleştirilen online mesleklerarası eğitiminin etkinliğini değerlendirdikleri çalışmalarında klinik uygulamalar ile eğitimin etkinliğinin arttırılabileceğini belirtmişlerdir. Brezis ve ark. (29) palyatif bakım hizmetlerinde önemli bir yer tutan yaşam sonu bakımda mesleklerarası simülasyon eğitiminin etkinliğini değerlendirdikleri nitel çalışmalarında, doktor ve hemşirelerden oluşan katılımcılar ekip çalışması kültürlerinin zayıf olduğunu belirtmişleridir. Bununla birlikte klinik uygulamada bazı doktorlar hemşireleri, hasta ile beraber yakınlarını bilgilendirme toplantılarına davet etmede isteksiz iken bazı doktorların ise hemşireleri ve diğer ekip üyelerini bilgilendirme toplantılarına rutin olarak katılmaya davet ettiklerini saptamışlardır. Özellikle farklı senaryolar ile oluşturulan simülasyona dayalı mesleklerarası eğitimin klinik uygulamalar ile sürdürülmesinin palyatif bakım hizmetlerinin istendik düzeye ulaşmasına ve ekip çalışmasının öneminin daha iyi anlaşılmasında katkıda bulunacağı düşünülmektedir.

\section{Araştırmanın Sınırlılıkları}

Öğrenciler, her ne kadar araştırmacılara jinekolojik onkoloji palyatif bakımda simülasyona dayalı mesleklerarası eğitime yönelik görüş, düşünce ve önerilerini ayrıntılı olarak aktarmaya istek ve eğilim göstermiş olsalar da elde edilen verilerin sınırlarını önemli ölçüde öğrencilerin belirlediğini vurgulamak gerekir. Araştırmacılar, farklı meslek grubundan oluşan ögrencilerin kendi programlarının yoğunluğu nedeniyle odak grup görüşmelerini planlama ve yürütme konusunda zorluk yaşamışlardır. Araştırmacıların yaşadığı bir diğer zorluk, farklı meslek gruplarında araştırmanın yürütülmesi nedeniyle, öğrencilerin fakülte/bölüm yönetimlerinden izin alma süreci ile ilgilidir. Araştırmanın uygulama aşamasının başlaması için gerekli olan izin alma sürecinin uzaması (fakülte/bölümlerin farklı zamanlarda araştırmanın uygulanabilmesi hususunda izin vermesi), bu aşamanın gecikmesi kaygısına neden olmuştur.

\section{SONUÇ VE ÖNERILER}

Jinekolojik onkolojiye yönelik palyatif bakım hizmetlerinin iyileştirilebilmesi ve hasta ve ailelerine yönelik kaliteli bakımın sağlanabilmesi için palyatif bakım hizmeti sunacak ekibin, disipline özgü bilgi ve becerilerine yönelik ortak bir anlayış geliştirerek mesleklerarası işbirliği içerisinde çalışmaları gerekmektedir. Mesleklerarası eğitim ile sağlık profesyonellerinin lisans eğitimlerinden itibaren birbirlerini tanımaları ve anlamaları sağlanarak işbirliği içerisinde çalışabilmelerine katkı sağlanabilir. Araştırmada farklı disiplinlerden oluşan ve simülasyon müdahalelerine katılan ögrrenciler ile yapılan nitel görüşmeler sonucunda öğrenciler, palyatif bakımda ekip çalışması ve mesleklerarası eğitimin önemini daha iyi anladıklarını; diğer mesleklerin rol ve sorumluluklarını öğrenebilmek, ekip olarak çalışabilmek, hasta güvenliğini ve hasta merkezli bakımın sağlayabilmek için simülasyona dayalı mesleklerarası eğitimin gerekli olduğunu belirtmişlerdir. Öğrenciler lisans eğitim müfredatlarında simülasyona dayalı mesleklerarası eğitimin gerekliliğini vurgulamışlardır. Öğrencilerin simülasyon uygulamaları ile teorik eğitimde öğrendikleri daha iyi pekiştirdikleri, yanlışlarını/hatalarını düzeltme firsatı buldukları, mesleki profesyonelliklerinin farkına vardıkları belirlenmiştir. Türkiye'de hemşirelik ve diğer sağlık profesyonellerinin eğitiminde araştırmamızda olduğu gibi bir öğrenme deneyimi sağlayan palyatif bakım eğitim programı bulunmamaktadır. Araştırmanın sonuçları, palyatif bakıma yönelik simülasyon yöntemlerine dayalı mesleklerarası eğitimin önemini ortaya çıkardığ için literatürde yer alan boşluğun doldurulmasına katkı sağlayacaktır. Palyatif bakım eğitimi, sadece hemşirelik eğitimi içerisine değil, gelecekte ekip olarak çalışabilecek diğer mesleklerin eğitimi içerisine entegre de edilmelidir. Mesleklerarası eğitime, sağlık profesyonellerinin lisans eğitiminin ilk yıllarından itibaren başlanılması; lisans eğitiminde yer alan öğretim üye ve elemanlarının simülasyona dayalı mesleklerarası eğitim ile ilgili ulusal ve uluslararası bilgi, beceri ve deneyim kazanmaları amacıyla teşvik edilmeleri önerilmektedir.

\section{TEŞEKKÜR}

Bu araştırma (Proje No: 117S900) 1002 Hizlı Destek Programı kapsamında Türkiye Bilimsel ve Teknolojik Araştırma Kurumu (TÜBİTAK) tarafından desteklenmiştir. Desteklerinden dolayı TÜBİTAK'a teşekkür ederiz.

\section{KAYNAKLAR}

1. Uslu Sahan F, Terzioglu F. Nurses' knowledge and practice toward gynecologic oncology palliative care. J Palliat Care Med. 2017; 7(4): 1-5.

2. Terzioglu F, Uslu Sahan F. Palliative care in gynecologic cancers. J Palliat Care Med. 2016; 6(5): 25-7.

3. Terzioğlu F, Uslu F. Palliative care to the cancer patient: Turkish nurses' perspectives. J Palliat Care Med. 2015; 5(4): 1-5.

4. nationalconsensusproject.org [Internet]. Pittsburgh: National Consensus Project Quality Palliative; 2013 [Updated: 2018 May 24; Cited: 2019 July 8]. Available from: https://www.nationalcoalitionhpc.org /wp-content/uploads/2017/04/NCP_Clinical_ Practice_Guidelines_3rd_Edition.pdf. 
5. sgo.org [Internet]. 2013 [Updated: 2013 January 4; Cited: 2019 July 8]. Available from: https://www.sgo.org/choosing-wisely/.

6. kanser.org [Internet]. Ankara; 2010 [Son güncelleme tarihi: 10 Aralık 2010; Erişim tarihi: 8 Temmuz 2019]. Erişim adresi:

https://www.kanser.org/saglik/userfiles/file/11Mayis2 011/turkiye_onkoloji_hizmetleri_kitapcik.pdf.

7. Silbermann M, Fink RM, Min S-J, Mancuso MP, Brant J, Hajjar R, et al. Evaluating palliative care needs in Middle Eastern Countries. J Palliat Med. 2015; 18(1): 18-25.

8. Turgay G, Kav S. Turkish healthcare professionals' views on palliative care. J Palliat Care. 2012; 28: 267-73.

9. Bahçecioğlu Turan G, Türben Polat H, Mankan T. İntörn hemşirelik öğrencilerinin palyatif bakima ilişkin görüşleri. Cumhur Hemşirelik Derg. 2017; 6(2): 54-60.

10. Çitil R, Okan İ, Önder Y, Çeltek NY, Süren M, Bulut YE, et al. Tip Fakültesi öğrencilerinin palyatif bakım konusundaki farkındalıklarının değerlendirilmesi. Bezmialem Science. 2018; 6(2): 100-7.

11. Efstathiou N, Walker WM. Interprofessional, simulation-based training in end of life care communication: A pilot study. J Interprof Care. 2014; 28(1): 68-70.

12. Fineberg IC, Wenger NS, Forrow L. Interdisciplinary education: Evaluation of a palliative care training intervention for pre-professionals. Acad Med. 2004; 79(8): 769-76.

13. Starks H, Coats H, Paganelli T, Mauksch L, Van Schaik E, Lindhorst $\mathrm{T}$, et al. Pilot study of an interprofessional palliative care curriculum: Course content and participant-reported learning gains. Am J Hosp Palliat Med. 2018; 35(3): 390-7.

14. Prelock PA, Melvin C, Lemieux N, Melekis K, Velleman S, Favro MA. One Team - patient, family, and health care providers: An interprofessional education activity providing collaborative and palliative care. Semin Speech Lang. 2017; 38(5): 350-9.

15. caipe.org [Internet]. Fareham: Centre for the Advancement of Interprofessional Education; 2017 [Updated: 2017 August 4; Cited: 2019 July 8]. Available from: https://www.caipe.org/resources/ publications/caipe-publications/caipe-2017interprofessional-education-guidelines-barr-h-ford-jgray-r-helme-m-hutchings-m-low-h-machin-reeves-s.

16. Lefebvre K, Wellmon R, Ferry D. Changes in attitudes toward interprofessional learning and collaboration among physical therapy students following a patient code simulation scenario. Cardiopulm Phys Ther J (Lippincott Williams Wilkins). 2015; 26(1): 8-14.

17. Birk TJ. Principles for developing an interprofessional education curriculum in a healthcare program. J Healthc Commun. 2017; 2(1): 1-4.

18. Wilhaus J, Palaganas J, Manos J, Anderson J, Cooper A, Jeffries P, et al. ssih.org [Internet]. 2013 [Updated: 2013 March 8; Cited: 2019 July 8]. Available from: http://www.ssih.org/LinkClick.aspx?fileticket=FQKv $\mathrm{yEp} 0 \mathrm{k} 3 \mathrm{k}=$ \&portalid=48.
19. Costello M, Huddleston J, Atinaja-Faller J, Prelack K, Wood A, Barden J, et al. Simulation as an effective strategy for interprofessional education. Clin Simul Nurs. 2017; 13(12): 624-7.

20. Baker C, Pulling C, McGraw R, Dagnone JD, Hopkins-Rosseel D, Medves J. Simulation in interprofessional education for patient-centred collaborative care. J Adv Nurs. 2008; 64(4): 372-9.

21. Pınar G. Simulation-enhanced interprofessional education in health care. Creat Educ. 2015; 6(17): 1852-9.

22. Jimenez YA, Thwaites DI, Juneja P, Lewis SJ. Interprofessional education: Evaluation of a radiation therapy and medical physics student simulation workshop. J Med Radiat Sci. 2018; 65(2): 1-8.

23. Wang JN, Petrini M. Chinese health students' perceptions of simulation-based interprofessional learning. Clin Simul Nurs. 2017; 13(4): 168-75.

24. Randall D, Garbutt D, Barnard M. Using simulation as a learning experience in clinical teams to learn about palliative and end-of-life care: A literature review. Death Stud. 2018; 42(3): 172-83.

25. Kotsakis A, Mercer K, Mohseni-Bod H, Gaiteiro R, Agbeko R. The development and implementation of an inter-professional simulation based pediatric acute care curriculum for ward health care providers. J Interprof Care. 2015; 29(4): 392-4.

26. Wagner J, Liston B, Miller J. Developing interprofessional communication skills. Teach Learn Nurs. 2011; 6(3): 97-101.

27. Joekes K, Brown J, Boardman K, Tincknell L, Evans D, Amy Spatz. Hybrid simulation for integrated skills teaching. Int J Clin Ski. 2016; 10(1): 1-5.

28. Cunningham S, Foote L, Sowder M, Cunningham C. Interprofessional education and collaboration: A simulation-based learning experience focused on common and complementary skills in an acute care environment. J Interprof Care. 2018; 32(3): 395-8.

29. Brezis M, Lahat Y, Frankel M, Rubinov A, Bohm D, Cohen MJ, et al. What can we learn from simulationbased training to improve skills for end-of-life care? Insights from a national project in Israel. Isr J Health Policy Res. 2017; 6(1): 1-9.

30. Pastor DK, Cunningham RP, White PH, Kolomer S. We have to talk: Results of an interprofessional clinical simulation for delivering bad health news in palliative care. Clin Simul Nurs. 2016; 12(8): 320-7.

31. Saylor J, Vernoony S, Selekman J, Cowperthwait A. Interprofessional education using a palliative care simulation. Nurse Educ. 2016; 41(3): 125-9.

32. Yıldırım A, Şimşek H. Sosyal bilimlerde nitel araştırma yöntemleri. Ankara: Seçkin Yayınevi; 2018.

33. Jeong $\mathrm{H}$, Othman J. Using interpretative phenomenological analysis from a realist perspective. The Qualitative Report. 2016; 21(3): 558-70.

34. Collins KM, Onwuegbuzie AJ, Jiao QG. Prevalence of mixed-methods sampling designs in social science research. Evaluation and Research in Education. 2006; 19(2): 83-101.

35. Creswell JW, Miller DL. Determining validity in qualitative inquiry. Theory Into Practice. 2000; 39(3): 124-30. 
36. Caylor S, Aebersold M, Lapham J, Carlson E. The use of virtual simulation and a modified TeamSTEPPSTM training for multiprofessional education. Clin Simul Nurs. 2015; 11(3): 163-71.

37. Rutherford-Hemming $\mathrm{T}$, Lioce L. State of interprofessional education in nursing: A systematic review. Nurse Educ. 2018; 43(1): 9-13.

38. Sicat BL, Huynh C, Willett R, Polich S, Mayer S. Interprofessional education in a primary care teaching clinic: Findings from a study involving pharmacy and medical students. J Interprof Care. 2014; 28(1): 71-3. 